\title{
Experiences and Conceptualisation of Spinal Intramedullary Tuberculoma Management
}

\author{
Manish Jaiswal, Ashok Gandhi, Achal Sharma, Radhey Shyam Mittal \\ Department of Neurosurgery, SMS Medical College and Hospital, Rajasthan, India
}

Objective: Spinal intramedullary tuberculoma (SIMT) is rare, accounting for $2 / 100,000$ cases of tuberculosis and only $0.2 \%$ of all cases of central nervous system (CNS) tuberculosis. We share our experiences of 11 cases of this entity for improving diagnosis and conceptualize the management of this rare disease.

Methods: The clinical profile, radiological data and management of 11 cases of SIMT which were managed either conservatively or by surgical intervention during last 27 years (1987-2014) were analysed.

Results: Male:female ratio was 1.75:1. Five cases had associated pulmonary Koch's. Most common site was thoracic cord. Two cases had concurrent multiple intracranial tuberculoma. Most common presentation was paraparesis. X-ray myelography was performed in two patients in the initial period of study suggesting intramedullary pathology. In the subsequent nine cases who had magnetic resonance imaging (MRI), seven showed typical "target sign" and conglomerate ring lesion. Out of 8 surgically managed patients, 6 cases improved rapidly and in 2 patients gradual improvement was seen in follow-up. Most common indication of surgical excision was rapid neurological deterioration followed by diagnosis in doubt. Histopathology confirmed tuberculous etiology of the intramedullary lesion in all. Clinical and radiological improvement was seen in all 3 conservatively managed patients in follow-up.

Conclusion: MRI findings of SIMT were specific and proven histologically correct. Surgical intervention may be indicated if there is no response to chemotherapy, the diagnosis is in doubt, or there is a rapid deterioration in neurological function because surgical outcome is good in these circumstances.

Key Words: Intramedullary $\cdot$ Tuberculoma $\cdot$ Tuberculosis $\cdot$ Spinal

\section{INTRODUCTION}

Although spinal tuberculosis (Pott's spine or intradural extramedullary tuberculoma) is relatively common in developing countries, spinal intramedullary tuberculoma (SIMT) is rarely seen $^{25)}$. Since it was first reported by Cascino and Dibble ${ }^{4)}$ in 1956, there have been only occasional case reports. In 2002, Sharma et al. ${ }^{22)}$ reported the largest group of SIMT. Presentation of SIMT is somewhat similar to intramedullary spinal cord tumour but when diagnosed in time and managed accor-

\footnotetext{
- Received: November 9, 2014 • Revised: March 3, 2015

- Accepted: March 4, 2015

Corresponding Author: Manish Jaiswal, MD

Department of Neurosurgery, SMS Medical College \& Hospital, Jaipur, Rajasthan, Varanasi, India

Tel: +91-979-998-04-94, Fax: +97-999-804-94

E-mail: manishmInmc@gmail.com

*No previous presentation of the manuscript or it part is done in any conference.

$\otimes$ This is an Open Access article distributed under the terms of the Creative Commons Attribution Non-Commercial License (http://creativecommons.org/ licenses/by-nc/3.0/) which permits unrestricted non-commercial use, distribution, and reproduction in any medium, provided the original work is properly cited.
}

dingly, outcomes is much better. We summarized the management of 11 cases of SIMT and reviewed the literature to improve diagnosis along with conceptualization of management of this rare but important entity.

\section{MATERIALS AND METHODS}

Hospital records of neurosurgery unit over 27 years (19872014) were retrospectively analysed in terms of clinical profile, radiological findings and treatment outcomes for the cases of SIMT which were managed either conservatively or by surgical intervention. Neurological ambulatory status were evaluated using the modified McCormick Scale $(\text { Table } 1)^{16}$. Total

Table 1. Modified McCormick scale for gait assessment in spinal intramedullary lesion

\begin{tabular}{ll}
\hline \hline Grade I & Normal gait \\
\hline Grade II & Mild gait disturbance not requiring support \\
Grade III & Gait with support \\
Grade IV & assistance required \\
Grade V & Wheel chair/bed ridden \\
\hline
\end{tabular}


11 cases were found in this category. Seven patients were male and four were female with ratio of 1.75:1. Age group ranges from 1.5 year old child to 45 years old patient. X-ray spine, X-ray chest, computed tomography (CT) thorax, myelogragraphy (in initial two patients) and magnetic resonance imaging (MRI) spine with contrast were performed to diagnose the disease and to detect primary or associated pathology. Haemogram and erythrocyte sedimentation rate (ESR) were done in all cases. Human immunodeficiency virus (HIV) serological examination was done in five cases associated with pulmonary Koch's and all were HIV negative. Depending on the clinical condition and response to anti tubercular therapy (ATT), three patients were kept on conservative anti-tuberculous management and eight were operated followed by ATT. Histopathological examination of excised biopsy confirmed the tuberculoma in all eight operated patients. Patients were followed up ranging from 2 to 3 years for clinical assessment. Repeat MRI spine and liver function test were advised in follow-up (to know the side effect of ATT on the liver and regression of the size of lesion on MRI). Clinical summary of all 11 patients are given in Table 2.

Table 2. Clinical summary of patients having spinal intramedullary tuberculoma

\begin{tabular}{|c|c|c|c|c|c|}
\hline Case & $\begin{array}{l}\text { Age in years/ } \\
\text { Sex }\end{array}$ & Presentations & $\begin{array}{l}\text { Investigation/Myelogram/ } \\
\text { MRI finding/Site }\end{array}$ & Management & Follow-up \\
\hline 1 & 29/Female & $\begin{array}{l}\text { Low backache, Urinary } \\
\text { retention, Sensory deficit. } \\
\text { McCormick's grade II. }\end{array}$ & $\begin{array}{l}\text { Myelography- Dorsal (D) } 12 \text { to } \\
\text { Lumber (L) } 1 \text { level } \\
\text { intramedullary lesion }\end{array}$ & $\begin{array}{l}\text { Decompressive laminectomy with } \\
\text { excision of tuberculoma \& ATT for } \\
2 \text { years }\end{array}$ & $\begin{array}{l}\text { Improved. } \\
\text { McCormick's grade I. }\end{array}$ \\
\hline 2 & 1.5/Male & $\begin{array}{l}\text { Urinary incontinence, spastic } \\
\text { paraparesis. } \\
\text { McCormick's grade III }\end{array}$ & $\begin{array}{l}\text { Myelography- D8 to D10 } \\
\text { intramedullary lesion }\end{array}$ & $\begin{array}{l}\text { Decompressive laminectomy with } \\
\text { excision of tuberculoma \& ATT for } \\
2 \text { years }\end{array}$ & $\begin{array}{l}\text { Improved. } \\
\text { McCormick's grade I }\end{array}$ \\
\hline 3 & 24/Male & $\begin{array}{l}\text { Fever, Spastic paraparesis, } \\
\text { back pain, sensory deficit. } \\
\text { McCormick's grade III }\end{array}$ & $\begin{array}{l}\text { MRI- D } 3 \text { to D4 Level Cord } \\
\text { expantion with target sign }\end{array}$ & $\begin{array}{l}\text { ATT followed by Decompressive } \\
\text { laminectomy with excision of } \\
\text { tuberculoma \& AT for } 2 \text { years }\end{array}$ & $\begin{array}{l}\text { Improved. } \\
\text { McCormick's grade ॥ }\end{array}$ \\
\hline 4 & 35/Female & $\begin{array}{l}\text { Fever, Cough, spastic } \\
\text { paraparesis. } \\
\text { McCormick's grade IV }\end{array}$ & $\begin{array}{l}\text { MRI- D5 to D6 Level Cord } \\
\text { expantion with target sign }\end{array}$ & $\begin{array}{l}\text { ATT followed by Decompressive } \\
\text { laminectomy with excision of } \\
\text { tuberculoma \& AT for } 2 \text { years }\end{array}$ & $\begin{array}{l}\text { Improved. } \\
\text { McCormick's grade ॥ }\end{array}$ \\
\hline 5 & 45/Male & $\begin{array}{l}\text { Fever, cough with sputum, } \\
\text { urinary retention, spastic } \\
\text { paraparesis. } \\
\text { McCormick's grade III }\end{array}$ & $\begin{array}{l}\text { MRI- D4 to D5 Level Cord } \\
\text { expantion with Heterogenous } \\
\text { hyperintese intramedullary } \\
\text { lesion }\end{array}$ & $\begin{array}{l}\text { ATT followed by Decompressive } \\
\text { laminectomy with excision of } \\
\text { tuberculoma \& AT for } 2 \text { years }\end{array}$ & $\begin{array}{l}\text { Improved. } \\
\text { McCormick's grade I }\end{array}$ \\
\hline 6 & 28/Male & $\begin{array}{l}\text { Urinary retention, Spastic } \\
\text { paraparesis. } \\
\text { McCormick's grade V }\end{array}$ & $\begin{array}{l}\text { MRI- D6 to D9 Level Cord } \\
\text { expantion with target sign }\end{array}$ & $\begin{array}{l}\text { Decompressive laminectomy with } \\
\text { excision of tuberculoma \& ATT for } \\
2 \text { years }\end{array}$ & $\begin{array}{l}\text { Post- operative Cord } \\
\text { edema in MRI spine, } \\
\text { Improved in } 3 \text { months } \\
\text { follow-up. } \\
\text { McCormick's grade ॥ }\end{array}$ \\
\hline 7 & 10/Male & $\begin{array}{l}\text { Urinary incontinence, } \\
\text { McCormick's grade ॥ }\end{array}$ & $\begin{array}{l}\text { MRI- LIConus Level target } \\
\text { sign }\end{array}$ & $\begin{array}{l}\text { Decompressive laminectomy with } \\
\text { excision of tuberculoma \& ATT for } \\
2 \text { years }\end{array}$ & $\begin{array}{l}\text { Improved. } \\
\text { McCormick's grade I }\end{array}$ \\
\hline 8 & 42/Male & $\begin{array}{l}\text { Acute quadriparesis, urinary } \\
\text { retention. } \\
\text { McCormick's grade IV }\end{array}$ & $\begin{array}{l}\text { MRI- Cervical (C) } 3 \text { to C6 Level } \\
\text { Cord expantion with } \\
\text { heterogenous hyperintense } \\
\text { intramedullary lesion }\end{array}$ & $\begin{array}{l}\text { Decompressive laminectomy with } \\
\text { excision of tuberculoma \& ATT for } \\
2 \text { years }\end{array}$ & $\begin{array}{l}\text { CSF Leak stopped on } \\
\text { conservative treatment, } \\
\text { Neurological status } \\
\text { remained same. } \\
\text { McCormick's grade ॥ }\end{array}$ \\
\hline 9 & 28/Female & $\begin{array}{l}\text { spastic paraparesis, } \\
\text { Headache, Vomitting, } \\
\text { papilaedema. } \\
\text { McCormick's grade ॥ }\end{array}$ & $\begin{array}{l}\text { Milliary tuberculosis in CT } \\
\text { thorax, D5 to D8 IMT (Target } \\
\text { sign) in MRI spine, Multiple } \\
\text { tuberculoma in frontal lobe in } \\
\text { MRI brain }\end{array}$ & $\begin{array}{l}\text { Conservative on ATT for } 2 \text { years } \\
\text { with steroid in initial } 3 \text { months. }\end{array}$ & $\begin{array}{l}3 \text { year follow-up, } \\
\text { Improved. } \\
\text { McCormick's grade I }\end{array}$ \\
\hline 10 & 37/Female & $\begin{array}{l}\text { Urinary stress incontinence, } \\
\text { Previous ATT history for } \\
\text { pulmonary Koch's. } \\
\text { McCormick's grade ॥ }\end{array}$ & $\begin{array}{l}\text { MRI- L1 (conus) level Target } \\
\text { sign }\end{array}$ & $\begin{array}{l}\text { Conservative on ATT for } 1.5 \text { years } \\
\text { with steroid in initial } 3 \text { months. }\end{array}$ & $\begin{array}{l}\text { Improved. } \\
\text { McCormick's grade I }\end{array}$ \\
\hline 11 & 20/Male & $\begin{array}{l}\text { Fever, paraparesis, } \\
\text { Headache, Blurring of vision. } \\
\text { McCormick's grade I }\end{array}$ & $\begin{array}{l}\text { Milliary tuberculosis in X-ray } \\
\text { chest, D12 \& L1 (conus) level } \\
\text { Target sign in MRI spine, } \\
\text { Multiple tuberculoma in MRI } \\
\text { brain }\end{array}$ & $\begin{array}{l}\text { Conservative on ATT for } 2 \text { years } \\
\text { with steroid in initial } 3 \text { months. }\end{array}$ & $\begin{array}{l}\text { Improved. } \\
\text { McCormick's grade I }\end{array}$ \\
\hline
\end{tabular}




\section{RESULTS}

Common preoperative symptoms of myelopathy were: paraparesis in 9 (81\%) cases, bladder bowel symptoms in 7 (63.6.\%) cases, numbness in $2(18 \%)$ cases, pain, quadriparesis, Brown Sequard syndrome and paraplegia each in $1(9 \%)$ case. On assessement of gait disturbance according to McCormic Grade, 1 patient in Grade I, 4 in Grade II, 3 in Grde III, 2 in Grade IV and 1 in Grade V were catogorized. Case no. 9 developed

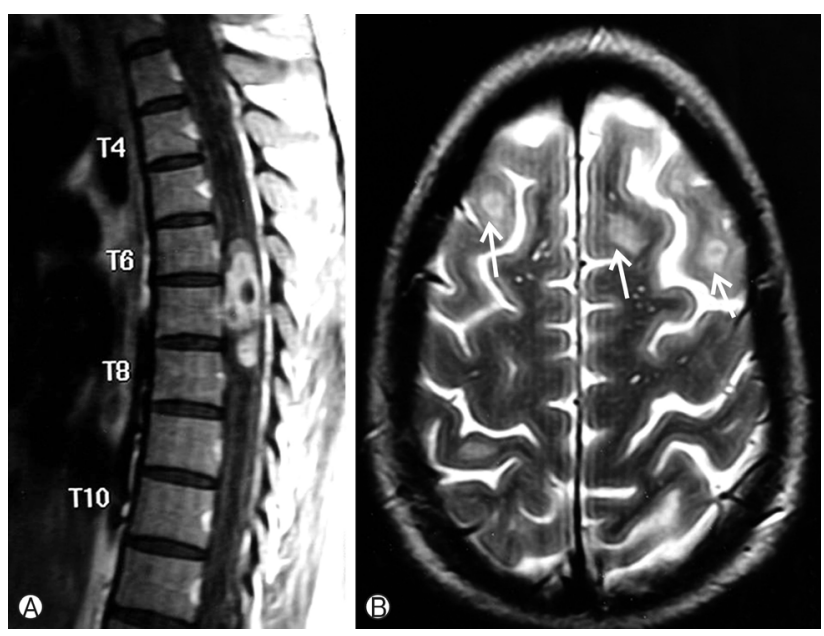

Fig. 1. Case 9 (A) Magnatic resonance imaging (MRI) spine with contrast showing conglomerate rim enhancing lesion suggestive of Dorsal 6-7 level intramedullary tuberculoma and (B) MRI brain revealed concomitant bilateral frontal tuberculoma in follow-up.
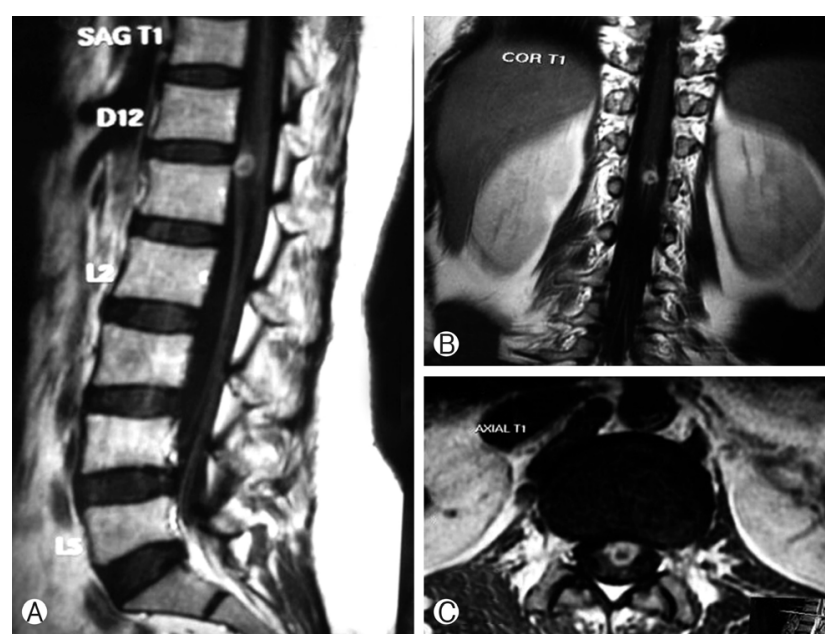

Fig. 2. MRI spine of Case 10 showing well defined regular rim enhancing lesion in anterior aspect of conus at D12-L1 level with mild leptomeningeal enhancement suggestive tuberculoma (A) Sagittal T1 post-contrast, (B) coronal post-contrast and (C) T2 axial images. headache with blurring of vision in follow-up \& MRI brain revealed concurrent multiple intracranial tuberculoma in frontal region (Fig. 1) which responded to ATT. Case no. 11 of paraparesis had associated headache, blurring of vision, ataxia and seizure at the time of admission suggestive of intra cranial pathology too. Five patients had history of evening rising fever with duration between 3 to 4 months, cough with sputum and respiratory symptoms suggestive of pulmonary tuberculosis. Of these five patients, three patients were on ATT since 4 to 6 months.

X-ray myelogram was performed in two cases (Case no. 1 and 2) in early period of study, which had finding suggestive of intramedullary pathology at the dorsal (D) spine level of D12 and D8 vertebra respectively. In later phase of study MRI spine was done in next 9 cases. Most common MRI finding was diffuse cord expansion at the site of lesion (In all 9 MRI finding) followed by characteristic Target sign (Hypointense on T1, Hyperintense ring enhancing lesion with central hypointensity) found in seven cases (Fig. 2).

Most common site of lesion was mid dorsal region found in 5 cases followed by lower end of cord found in 4 cases. There was one case of cervical SIMT (case no. 8). Multiple intramedullary lesions were found in two cases (case no. $9 \&$ 11). Case no. 11 (having conus region intramedullary target sign in MRI spine) who had headache, seizure and blurring of vision along with paraparesis, MRI brain with Gadoliniun enhancement revealed multiple intracranial tuberculoma (Fig. 3 and Fig. 4). There was no vertebral body involvement in any
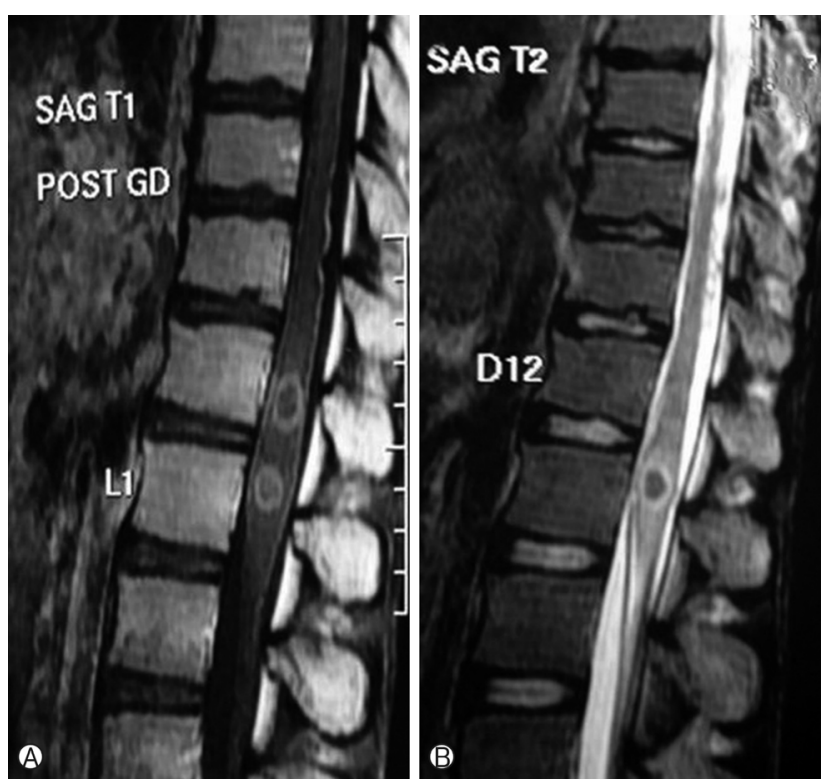

Fig. 3. Case $11 \mathrm{MRI}$ spine showing typical target sign at conus \& epiconus region (A) post-contrast sagittal image, (B) T2 weighted image. 
case. X-ray chest (Fig. 5A) and CT thorax (Fig. 5B) revealed pulmonary tuberculosis in five cases (all were HIV negative). ESR was raised in 9 out of 11 patients.

Out of 11 patients of SIMT (MRI spine having typical target sign), 3 patients were managed conservatively on ATT (Isoniazid (H) $5 \mathrm{mg} / \mathrm{Kg} /$ day, Rifampin (R) $10 \mathrm{mg} / \mathrm{Kg} /$ day, Etambutol (E) $15 \mathrm{mg} / \mathrm{Kg} /$ day, Pyrazinamide (Z) $25 \mathrm{mg} / \mathrm{Kg} /$ day, Streptomycin (S) $15 \mathrm{mg} / \mathrm{Kg} /$ day and Moxifloxacin (M) $10 \mathrm{mg} / \mathrm{Kg} /$ day for 3 months in intensive phase followed by two drug regime $(\mathrm{HR})$ in continuance phase for 21 months. Oral corticosteroid (Prednisolone $1 \mathrm{mg} \mathrm{Kg} /$ day) in tapering dose was given for the initial 6 weeks of intensive phase. Indication of conservative management in these 3 patients was followings:

1) Two (case no. 9 and 10) were taking ATT for pulmonary Koch's for 3-4 months and neurological status was non progressive in nature and stable in initial phase of ATT.

2) Multiple intracranial and SIMT in MRI and clinical fea-

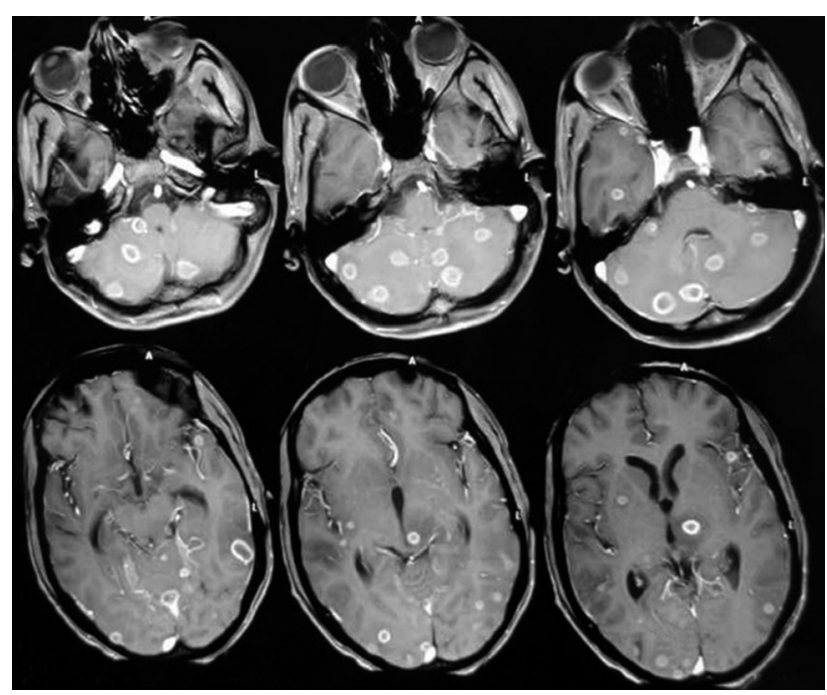

Fig. 4. Case 11 MRI brain with contrast revealed concurrent multiple intracranial tuberculoma.
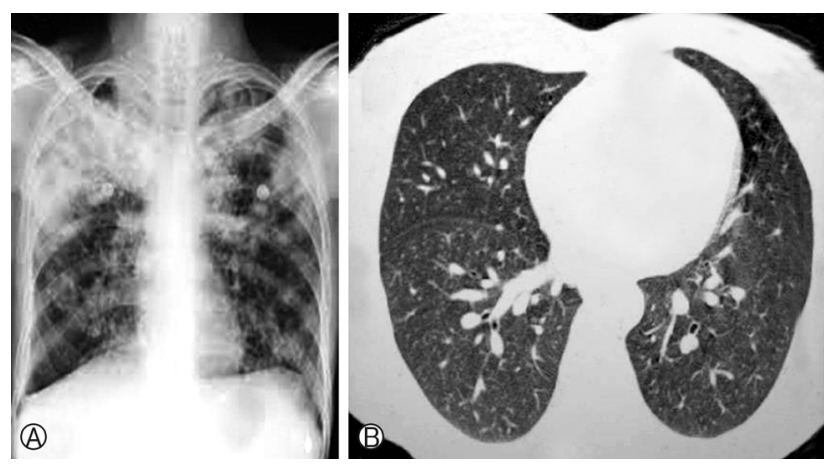

Fig. 5. (A) X-ray chest of Case 11 and (B) CT thorax of Case 9 suggestive of associated miliary tuberculosis. ture along with X-ray chest suggestive of pulmonary Koch's (case no. 9 and 11).

Surgical excision of SIMT after decompressive laminectomy of the corresponding level was performed in 8 cases (Fig. 6A). Indications of surgical intervention were following:

1) No response to chemotherapy (ATT).

2) Diagnosis in doubt (MRI finding suggestive of Intramedullary tumour in differential diagnosis) in patient with no history of pulmonary tuberculosis.

3) There was a rapid deterioration in neurological function.

4) Paradoxical increase in size with mass effect after ATT start (Case no. 8).

Well circumscribed yellow-grey mass located cortically and intramedullary region were found in all cases preoperatively (Fig. 6B). These lesions were very carefully dissected and totally resected along a definable plane by use of the operating microscope. The gross pathological specimens were encapsulated, yellow-grey firm mass which were sent to histopathological examination.

Pathological examination of the lesions revealed multiple epitheloid cell granulomas with Langerhan's and foreign body type of giant cells. Large areas of caseous necrosis were also seen in resected specimen (Fig. 6C). ATT for 2 years consist of six drug regimen (HRZESM) in intensive phase (3 months) and two drug regimen (HR) in continuation phase were given to overcome drug resistance.

Postoperative MRI showed total resolution of the lesion in seven out of eight operated patients. In one patient there was
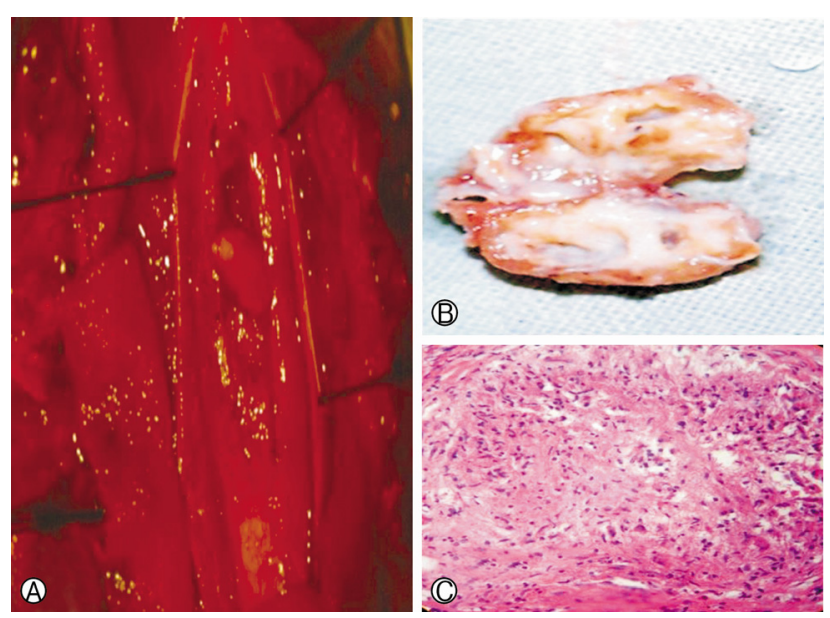

Fig. 6. (A) Preoperative photograph of spinal intramedullary tuberculoma excision, (B) postoperative specimen of excised tuberculoma showing central caseation and (C) histopathological examination finding showing multiple epitheloid cell granuloma with Langerhan's and foreign body type of giant cells confirming the diagnosis of tuberculoma. 
postoperative oedema which resolved in follow-up MRI at 3 months. One patient developed CSF leak postoperative day 4 which was successfully managed by Acetazolamide, prone position and compression dressing. Six patients improved significantly and rest two gradually in neurological status in terms of ambulation and spasticity in follow-up. Anti-spastic agent was also advised in post operative period in dose of Baclofen $10 \mathrm{mg}$ thrice a day. Three patients were managed conservative on ATT only, also responded well in follow-up at regular interval of 3 months, 6 months, 1 year and 2 years.

\section{DISCUSSION}

Tuberculosis is a chronic bacterial infection produced by Mycobacterium tuberculosis. Tuberculosis of the central nervous system is a rare entity, affecting $0.5-2 \%$ of patients with systemic tuberculosis ${ }^{17,20,23)}$. The first report of SIMT was by Abercrombie in $1828^{1)}$. SIMT is a lesion extremelly rare seen only 2 of 100,000 cases of all type of tuberculosis and 2 of 1,000 cases of CNS tuberculosis ${ }^{13,15}$. The ratio of intramedullary spinal to intracranial tuberculoma was found to be 1:42 in one major series ${ }^{5}$. In Dastur's excellent review and summary of their tuberculoma series, 260 cases were in the brain and six were in the cord. Of the 74 tuberculous paraplegias in this group, 44 were extradural, four were subdural, four combined subdural-extradural, and six were intramedullary ${ }^{\text {}}$. It is more common in young patients with pulmonary tuberculosis (69\% of cases) in the developing countries ${ }^{13,15}$. In our study 5 out of 11cases (45\%) had pulmonary tuberculosis.

Most of the reported SIMT are solitary. However, multiple SIMT have been increasingly reported after the use of MRI was introduced ${ }^{8,9,14,15)}$. Concurrent intracranial tuberculoma is extremely rare ${ }^{10,18,24,26,28)}$. In case no. 9 and 11, there were multiple SIMT with concomitant multiple intracranial tuberculoma. We suggest that MRI of the brain should be performed in the case of multiple SIMT because of the possible presence of early asymptomatic intracranial tuberculomas. These findings are important for the proper management of patients with spinal tuberculosis.

SIMT is mostly induced by hematogenous dissemination or cerebrospinal fluid infection. However, in a few cases, it is caused by local spreading of spinal tuberculosis. It is important to look for pulmonary tuberculosis or extrapulmonary tuberculosis in patients with SIMT. Chest radiographs and CT scanning are effective measures for the detection of pulmonary tuberculosis and extrapulmonary tuberculosis ${ }^{13,15)}$. SIMT most commonly involve the thoracic spinal cord ${ }^{19)}$. Same findings were present in our study with the involvement of dorsal cord in 10 out of 11 cases (91\%).
Patients frequently present with quadriplegia/paraplegia and with other signs of subacute spinal cord compression like progressive lower limbs weakness, paresthesia, and bladder and bowel dysfunction. The major physical findings were paraplegia, either spastic or flaccid. The majority of patients had thoracic sensory level ${ }^{15,22)}$. SIMT are also reported in patients with HIV, auto-immune disease, especially systemic lupus erythematosus and patients undergoing immunosuppressive treatment due to liver transplantation ${ }^{3)}$, so symptomatology of these associated co- morbid condition may be present. In our series there was no such co-morbid condition was detected.

All the patients must be completely evaluated in terms of primary focus, site and extent of the lesion and its correlation with manifestations. Usual investigative tools are MRI spine with contrast, X-ray chest, X-ray spine, ESR and/ or HIV serological examination. The best imaging modality for diagnosis is MRI because it can accurately show location, size, and number of lesions, as well as whether there is degeneration and necrosis around the lesions ${ }^{11}$. The differential diagnoses include common spinal intramedullary tumors, such as astrocytoma, ependymoma, and hemangioblastoma.

The MRI findings in cases of SIMT can vary during the different phases of tuberculoma. In the early phase, "target sign" is a valuable indicator that helps differentiate IMT from other intramedullary lesions. Rim enhancement is usually observed in SIMT. Compared with tumors, SIMT has a sharper margin and lower T2 weighted images signals, and it is particularly easy to differentiate the disease when there is a "target sign". Enhanced examination should be performed when diagnosis cannot be obtained by plain scanning. On MRI, signal intensities of tuberculomas are compared to signal intensities of the normal spinal cord. Tuberculomas appear hypo-isointense in T1 weighted images and have a slightly hyperintense rim $^{8,13,20)}$. On T2 weighted images, tuberculomas exhibit variable signals. They are hypointense or isointense, this relative hypointensity is related to $\mathrm{T} 2$ shortening by paramagnetic free radicals produced by macrophages that are heterogeneously distributed throughout the caseous granuloma. The diminished signal on T2 Weighted images is due to the mature tuberculoma being of greater cellular density ${ }^{8}$. Tuberculomas may also be hyperintense on T2 weighted images and this is due to a greater degree of central liquefactive necrosis in these lesions ${ }^{8,13)}$. Postgadolinium images of tuberculomas demonstrate intense nodular and ring like enhancement. Healed tuberculomas calcify in $23 \%$ of cases. The complete resolution of the lesions in the follow-up MRI after the institution of anti-tuberculous treatment is confirmative of the diagnosis of SIMT.

There is no unanimity regarding the management protocol. Given the rarity of SIMT, there is no standardized treatment 
protocol for this condition. Both surgical and medical treatment have yielded good results in different series ${ }^{1,27,11,12,22,27,28)}$. Many authors have recommended medical treatment of SIMT with good results ${ }^{7,21,24)}$.

MacDonnel has reported 65\% recovery after surgical treatment ${ }^{15)}$. Purpose of surgical intervention is to decompress the cord when progressing neurologic defects occur and also makes it possible to examine the tissue pathologically. Undue delay entailed by prolonged medical therapy might lead to irreversible cord damage, and the patient might not improve neurologically even if the lesion disappears radiologically. We believe that surgical intervention should be considered for cases showing progressive deficits in spite of adequate medical management and large lesions causing significant compression. With skilled microsurgical techniques, it is possible to safely excise the SIMT as these lesions are well circumscribed. As with any surgical procedure there are attendant risks of anesthesia and probability of developing post-surgical tuberculosis meningitis, sinus formation, and residual deficit ${ }^{8,15)}$.

Conservative management of SIMT, if diagnosed early usually has good response to medical treatment preventing the need for surgical intervention. Anti-tuberculosis medications and a short course of injectable steroids offers an effec- tive, inexpensive, safe, and feasible option for treating SIMT, especially in developing countries ${ }^{7,22)}$. Role of steroid is largely unproven. In all three conservatively managed patients, we had positive results with oral steroid for short period, when given along with ATT. Specially with perilesional oedema short-term steroids may be helpful ${ }^{15)}$. Usually the conservative treatment is successful in achieving complete clinical neurological recovery over a period of 1 to 2 years, which is also accompanied by resolution of the tuberculomas ${ }^{7,22)}$. Prospective studies are required to clarify the role of surgery and medical therapy in the treatment of these rare lesions. Brief conceptualization of the diagnosis and management of SIMT is tried by us for decision making (Table 3).

\section{CONCLUSION}

Although rare, this entity should be considered in the differential diagnosis of spinal cord lesions. Gadolinium enhanced MRI helps in the accurate diagnosis as well as in monitoring of SIMT in follow-up. Medical treatment with anti-tubercular drugs and corticosteroids is recommended in early diagnosed SIMT cases, as complete resolution of lesions is seen. Surgery is indicated in patients where, there is no response to chemo-

Table 3. Management of spinal intramedullary tuberculoma (SIMT)

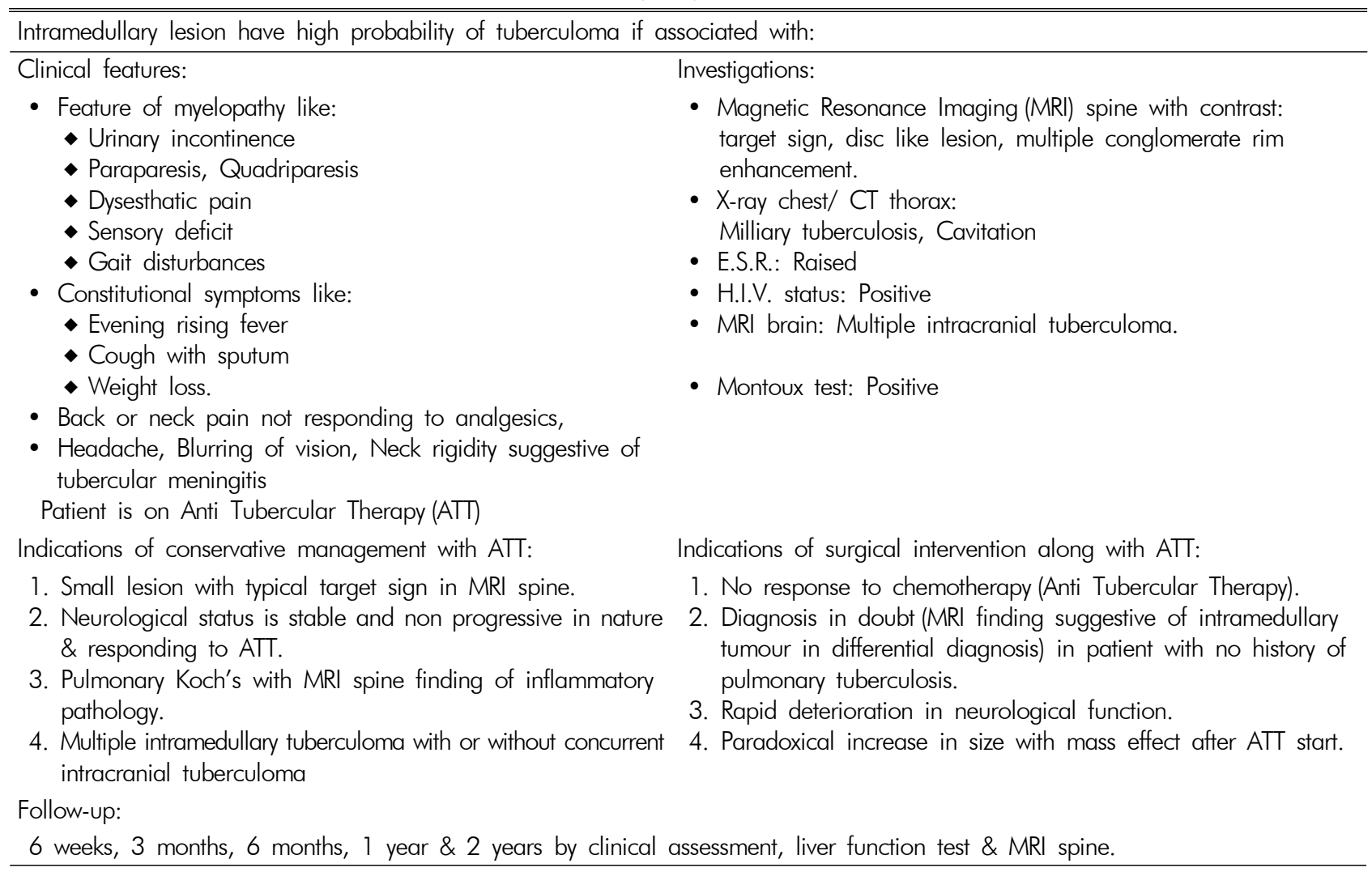


therapy, the diagnosis is in doubt, or there is a rapid deterioration in neurological function.

\section{REFERENCES}

1. Abercrombie J: Pathological and practical researches on disease of the brain and the spinal cord. Edinburg: Waugh and Innes: 371-372, 1828

2. Alessi G, Lemmerling M, Nathoo N: Combined spinal tuberculous empyema and intramedullary tuberculoma in an HIVpositive patient. Eur Radiol 13:1899-1901, 2003

3. Arslantas A, Faruk A,Kismet B,Esref T: Intramedullary tuberculoma of spinal cord. J Postgrad Med 48(1):54-5, 2002

4. Cascino J, Dibble JB: Tuberculoma of spinal cord. JAMA 162(5): 461-462, 1956

5. Citow JS, Ammirati M: Intramedullary tuberculoma of the spinal cord: Case report. Neurosurgery 35:327-330, 1994

6. Dastur HM: A tuberculoma review with some personal experiences: II. Spinal cord and its coverings. Neurol India 20(3):127131, 1972

7. Devi BI, Chandra S, Mongia S, Chandramouli BA, Sastry KV, Shankar SK: Spinal intramedullary tuberculoma and abscess: a rare cause of paraparesis. Neuro India 50:494-496, 2002

8. Gupta RK, Gupta S, Kumar S, Kohli A, Misra UK, Gujral RB: MRI in intraspinal tuberculosis. Neuroradiology 36:39-43, 1994

9. Gupta VK, Sharma BS, Khosla VK: Intramedullary tuberculoma: report of two cases with MRI findings. Surg Neurol 44:241-244, 1995

10. Huang CR, Lui CC, Chang WN, Wu HS, Chen HJ: Neuroimages of disseminated neurotuberculosis: report of one case. Clin Imaging 23:218-222, 1999

11. Jena A, Banerji AK,Tripathi RI, Gulati PK, Jain RK, Khushu S, et al: Demonstration of intramedullary tuberculosis by magnetic resonance imaging: a report of two cases. $\mathrm{Br} \mathrm{J}$ Radiol 64:555557, 1991

12. Kobayashi R, Togashi S, Nagasaka T, Shindo K, Shiozawa Z, Yamada $\mathrm{H}$, et al: Intramedullary tuberculoma with syringomyelia. J Spinal Disord Tech 15:88-90, 2000

13. Lin TH:Intramedullary tuberculoma of the spinal cord. J Neurosurg 17:497-499, 1960
14. Lin SK, Wu T, Wai YY: Intramedullary spinal tuberculoma during treatment of tuberculous meningitis. Clin Neuro Neurosurg 96:71-78, 1994

15. MacDonnell AH, Baird RW, Bronze MS: Intramedullary tuberculomas of the spinal cord : case report and review. Rev Infect Dis 12:432-439, 1990

16. McCormick PC, Stein BM: Intramedullary tumours in adults. Neurosurg Clin N Am 1:609-630, 1990

17. Mohit AA, Santiago P, Rostomily R: Intramedullary tuberculoma mimicking primary CNS lymphoma. J Neurol Neurosurg Psychiatry 75(11):1636-1638, 2004

18. Muthukumar N, Venkatesh G, Senthilbabu S, Rajbaskar R: Surgery for intramedullary tuberculoma of the spinal cord (report of 2 cases) Surg Neurol 66:69-74, 2006

19. Nussbaum ES, Rockswold GL, Bergman TA, Erickson DL, Seljeskog EL: Spinal tuberculosis: a diagnostic and management challenge. J Neurosurg 83(2):243-247, 1995

20. Parmar H, Shah J, Patkar D, Varma R: Intramedullary tuberculomas. MR findings in seven patients. Acta Radiol 41:572577, 2000

21. Rao GP: Spinal intramedullary tuberculous lesion: medical management. Report of four cases. J Neurosurg Spine 93:137-141, 2000

22. Ramdurg SR, Gupta DK, Suri A, Sharma BS, Mahapatra AK: Spinal intramedullary tuberculosis: a series of 15 cases. Clin Neurol Neurosurg 111(2):115-118, 2009

23. Ratliff JK: Intramedullary tuberculoma of spinal cord. J Neurosurg (Spine) 90:125-128, 1999

24. Shen WC, Cheng TY, Lee SK, Ho YJ, Lee KR: Disseminated tuberculomas in spinal cord and brain demonstrated by MRI with gadolinium-DTPA. Neurosurgery 35:213-215, 1993

25. Sohn S, Jin YJ, Kim KJ, Kim HJ: Long-term Sequela of Intradural Extramedullary Tuberculoma in the Thoracic Dorsal Spinal Cord: Case Report and Review of the Literature. Korean J Spine 8(4):295-299, 2011

26. Thacker MM, Puri AI: Concurrent intra-medullary and intracranial tuberculomas. J Postgrad Med 50:107-109, 2004

27. Torii H, Takahashi T, Shimizu H, Watanabe M, Tominaga T: Intramedullary spinal tuberculoma: case report. Neurol Med Chir 44:266-268, 2004

28. Yen HL, Lee RJ, Lin JW, Chen HJ: Multiple tuberculomas in the brain and spinal cord: a case report. Spine 28:499-502, 2003 